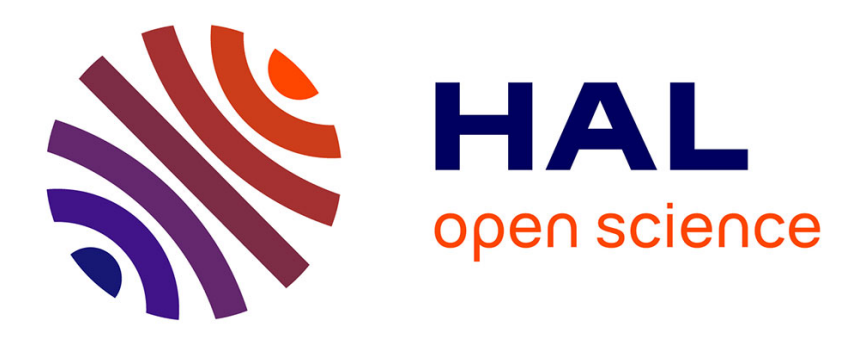

\title{
Insights for a Better Future in an Unfair World: Combining Social Justice with Sustainability
}

Francois Mancebo

\section{To cite this version:}

Francois Mancebo. Insights for a Better Future in an Unfair World: Combining Social Justice with Sustainability. Transitions to Sustainability, pp.105-116, 2015, 10.1007/978-94-017-9532-6_9 . hal02017762

\section{HAL Id: hal-02017762 \\ https://hal.univ-reims.fr/hal-02017762}

Submitted on 14 Feb 2019

HAL is a multi-disciplinary open access archive for the deposit and dissemination of scientific research documents, whether they are published or not. The documents may come from teaching and research institutions in France or abroad, or from public or private research centers.
L'archive ouverte pluridisciplinaire $\mathbf{H A L}$, est destinée au dépôt et à la diffusion de documents scientifiques de niveau recherche, publiés ou non, émanant des établissements d'enseignement et de recherche français ou étrangers, des laboratoires publics ou privés. 


\title{
Insights for a Better Future in an Unfair World: Combining Social Justice with Sustainability
}

\section{François Mancebo}

\begin{abstract}
One of the more challenging aspects of sustainability policies is to address social justice. Often, so-called sustainability initiatives turn out to be completely out of touch with the needs and expectations of the populations concerned, and contribute to increase social injustice. This is particularly true in urban areas, which are the ambit of this chapter. How to cope with this problem? Promoting people's place-based appropriation of sustainability policies looks like an interesting lead to follow. The challenge here is to address the social process of decisionmaking. Ultimately, the challenge is design a new social contract: matter in which a comprehensive understanding of the coordination mechanisms between the local, national, regional and international scale is crucial.
\end{abstract}

Keywords Transition to sustainability $\bullet$ Social process of decision-making $\bullet$ Urban planning • Multilevel governance $\bullet$ Imported sustainability

Achieving a livable and sustainable future in a changing world is a crucial challenge that our societies are facing. On this point, everybody agrees. Though, when it comes to determining how to do this practically, or simply what sustainability really is about, and, there is much less consensus. Addressing the antagonisms between social justice and sustainability is a way amongst many to address transition to sustainability. This chapter focuses on the sharp processes of spatial differentiation and the many-fold conflicts between urban sustainability and social justice.

The reason why it is so difficult to answer the basic question of what sustainability is lays into the fact that sustainable development is not only about science. It also is about ideas and values (Leiserowitz et al. 2006): various interpretations-frequently

François Mancebo is Full Professor of Planning and Sustainability at Rheims University. He is the head of the IRCS (International Research Center on Sustainability) and the director of the IATEUR (Institute of Regional Development, Environment and Urban Planning of Rheims). Email.francois.mancebo@univ-reims.fr

F. Mancebo $(\square)$

IATEUR IRCS, University of Reims Champagne-Ardenne, Campus Croix-Rouge,

57 bis avenue P. Taittinger, 51100 Reims Cedex, France

e-mail: francois.mancebo@univ-reims.fr 
divergent from one another-naturally thrive, since values may differ a lot between cultures and over time (Christen and Schmidt 2012). Starting with the release of the World Commission on Environment and Development report (WCED 1987), sustainable development began being widely discussed throughout the 1990s among international organizations. Rio's Agenda 21 has seen national and even regional and local governments enter the debate after 1992 (Eliott 2006). Progressively, sustainable development took on a multiplicity of sometimes-contradictory meanings (Robinson 2003). The situation is now so complex that it needs a mapping (Hopwood et al. 2005). However, the central idea is simple enough: Recognizing the finite nature of earth's biophysical resources, it promotes a type of development that meets our current needs without compromising those of the generations to come. When the United Nations assigned the redaction of a report to the World Commission on Environment and Development, its mission statement mentioned explicitly that its objectives were how to reduce inequality and poverty without damaging the environment granted to the future generations (WCED 1987). Such a statement entails serious difficulties: It is not so easy to balance the needs of our societies today (environmental justice, living conditions) with the needs of the future generations (preservation of the resources and protection of the planet).

This difficulty cuts across another one of the same nature: the theoretical divide between "weak" and "strong" sustainability (Haughton and Hunter 1994). Proponents of "weak" sustainability consider that manufactured capital can replace completely natural capital, as technology answers the environmental consequences of the production of goods and services: "the world can, in effect, get along without natural resources, so exhaustion is just an event, not a catastrophe" (Solow 1974). Proponents of "strong" sustainability consider that manufactured capital cannot replace perfectly natural capital, especially some global processes vital to the human existence such as the climate or the ozone layer (Daly 1998; Roseland 1998). In this perspective, it is crucial to limit the quantities of material and energy extracted from the biosphere and to reduce drastically the emission of pollutants (Von Weizsäcker et al. 1997; Lenton et al. 2008). Officially, of course, sustainable development is an integrative notion that should harmoniously unify these two types of sustainability (Giddings et al. 2002). The Brundtland report points out that the satisfaction of human aspirations should "not endanger the natural systems that support life on Earth: the atmosphere, the waters, the soils, and the living beings"..."It is part of our moral obligation to other living beings and future generations" (WCED 1987). But, simultaneously it promotes a more rapid economic growth in order to overcome poverty, in reference to the "trickle-down theory" which affirm that the economic grows finally benefit to everybody and as such reduce poverty (Dollar and Kraay 2000). Such an ambiguous position is of no help to clarify the link between the two types of sustainability. It creates confusion on what is the substance of sustainable development. Thus, it generates the gap between "weak" and "strong" sustainability, which finally is a gap between those who give poverty reduction and social justice today priority over the needs of the generation to come (which calls for "weak" sustainability), and those who think the opposite (which calls for "strong" sustainability). 


\section{How Sustainability May Fosters Injustice: A Focus on Urban Areas}

The challenge of combing social justice with sustainability policies is particularly crucial in urban areas. By 2050, $70 \%$ of the world's population will live in cities (UN-HABITAT 2008). Local authorities, when trying to make their city sustainable, have in common the objective of a better use of what is already there (Theys and Emelianoff 2001). Sustainable cities could thus be nicknamed "recyclable cities" in the sense that they are supposed to constantly recycle their urban fabric and their urban functions without going through phases of obsolescence with brownfield land and degraded neighborhoods, and without squandering soils (Swart et al. 2003). For example, new "ecological gardens" appeared at the end of the 90s, on the wastelands of former industrial sites of inner Paris and at the same time old industrial buildings of these sites were rehabilitated in eco-friendly construction (apartments or offices) (Duréault 2013). But even if recycling partly what is already there, these cities will have to provide water and energy to their inhabitants while reducing pollution and using sustainable resources. A challenge that requires radically new procedures and technical tools to manage traffic congestion, water and electricity networks, "intelligent buildings," while preserving the existing urban and social fabric. Therefore, urban areas are relevant research objects when trying to examine how to combine social justice with sustainability policies.

As shown by Elizabeth Burton in a large sample of UK towns, technical solutions may join with legal requirements in increasing social injustice (Burton 2001). Consider the particular case of sustainable housing: As far as sustainable housing is concerned, the reason why sustainable cities and ecological neighborhoods are mostly inhabited by wealthy people is simple: In the beginning, these categories were targeted because they could afford the higher construction costs, and because they were decisive in the formation of new trends. Such a choice was supposed to make easier the democratization of the access to these type of living, as larger demand would made possible lowering construction costs due to economies of scale. The Swedish cases of Hammarby Sjöstad (Stockholm) or Västra Hamnen (Malmö) illustrate this approach (Olander et al. 2007). However, this democratization did not happen. Construction costs inflated steadily, as developers, constrained by drastic environmental specifications, played the "style and class" card to increase their capital gains. Anyway, as higher as it can be, there are a limited number of ecological dwellings, and their attractiveness is strong. So, the law of supply and demand increases the rent rate and the sell rate, regardless what the construction cost is. This new upward pressure on prices brought by sustainable housing usually proves catastrophic (François et al. 2011). The name of "sustainable" neighborhood is inappropriate when a neighborhood becomes socially inaccessible. This leads some authors to denounce the veil thrown over profoundly unfair environmental dynamics that involve the departure of socially vulnerable people out of these places to outlying areas (Smith 2002). 
There is another issue concerning social justice here: wouldn't public money have been spent more efficiently if invested to reduce actual environmental disparities between areas, bettering places where the environmental conditions are already pretty bad? In the metropolitan region of Paris, for example, $50 \%$ of the places with degraded environment (pollution, nuisances) are also socially deprived; symmetrically, nearly $50 \%$ of those with good environmental conditions are wealthy areas (Bigot 2009). If we try to consider what is the main factor for such a distribution, the attractiveness of the communes with a nice environment appears less decisive than the avoidance of the nuisances of those with a poor one. What is interesting here, is that the residential choice is motivated by the rejection of environmental degradation rather than the attractiveness of environmental amenities (nature, silence, air and water quality, etc.) (Gueymard and Faburel 2008). Thus urban sustainability policies should focus on an inclusive approach, rather than to keep on creating "attractive" green housing spots haphazardly. More generally, sustainability policies should be conceived and implemented in areas large enough to take into account not the whole urban fabric.

\section{The Issue of Imported Sustainability}

When a place looks sustainable by giving to other places the burden of its transition to sustainability - exporting pollution and undesired products (waste and nuisances) or polluting activities, siphoning their resources and energy - this place is not really sustainable. It benefits from what David Pearce calls imported sustainability (Pearce et al. 1989), that is to say in the case of a urban area when a city transfers the cost of its sustainability onto adjacent or distant regions. Sometimes imported sustainability is an unintentional phenomenon, for example, fires in boreal peat lands may be sources of atmospheric mercury, transported and deposited far away (Turetsky et al. 2006).

Imported sustainability is a major bias against the implementation of sustainability policies. An effective sustainability policy should be conceived on an area large enough to internalize the imported sustainability bias, while taking into account all the relations between the human beings and the environment where they live (Elliot 2006). In the case of urban policies the only solution is defining them on extensive spatial scales, which include suburban, periurban and dependent rural, or natural areas (Donzelot 2004). It is all but evident, since limits will differ according to which aspect of sustainability we focus on: The functional area and the employment area of a major industrial center do not coincide, nor do they with the geographical area affected by the pollution (physical, chemical, air and water) and nuisance due to this industrial center. Thus, to avoid imported sustainability, urban sustainability policies should be conceived and implemented at three complementary scales simultaneously: 
- First is the scale of the neighborhood. A place based level. At this level the physical impact of the urban projects, even if they are conceived at the agglomeration level, is maximal.

- Second is the scale of agglomeration in urban planning. Which represents finally a cluster of adjacent neighborhoods working together. It gives a good insight of the urban policies, on the one side, and of the urban lifestyles, on the other side. This level plays a strategic role in sustainable urbanization. At this scale the coordination between multiple actors producing policies is crucial.

- Finally, there is the scale of the hinterland, which reflects the agglomeration environmental footprint. It is defined to include most of the fluxes of the urban metabolism (Billen et al. 2012). This level can be called "regional." It is crucial to describe imported sustainability, since it is supposed to encompass a significant part of the environmental footprint.

Determining concretely these three scales is tricky. Urban areas are covered with overlapping partitions: Each administration, each economic actor, each local community produces its own zoning and its own limits. So-called sustainability policies can have terrible effects when they do not take into account scales linkage.

\section{What Is a "Good" Environment? A Place-Based Perspective}

The context is important when cascading through spatial scales. Every person and community lives multiple affiliations, based on various territorial scales. Thus, sustainability policies must address the existing social a cultural fabric, legislation and planning traditions, communities, local assets and resources (Costanza et al. 2001). Thus to combine social justice with sustainability, it is fundamental to understand the linking between the societies and the ecosystem where they live in at different spatial scales (Carpenter et al. 2009). One of its expressions is spatial heterogeneity. For example, patterns of land use/land cover strongly influence hydrologic flow paths and delivery of nutrients to surface waters; patterns of agricultural and natu$\mathrm{ral} / \mathrm{semi}$-natural habitats affect the diversity and abundance of natural enemies that prey upon agricultural pests, etc. (Strayer et al. 2003; Werling and Gratton 2008). Humans often re-scale spatial patterns, increasing heterogeneity at large scales while reducing heterogeneity at small scales. For example, in agricultural areas, humans often impose coarse spatial patterns with sharp boundaries and greater contrast among land covers while homogenizing fine-scale variation in soil properties. The sharp boundaries, high contrast, and altered functional connectivity resulting from human activity may change the quantity, quality and variability of landscapes (Turner et al. 2008). In addition, this spatial heterogeneity reflects heterogeneity among people, cultures and institutions that affects sustainability and social justice (Turner 2010). When considering this, societies appear as complex adaptive systems, composed of individual agents who have their own priorities, and who value the macroscopic features of their societies differently. Resolving those competing 
perspectives is at the core of transition to sustainability. Complex adaptive systems, integrate change from individuals to whole systems, across scales. The recurring question of which coordination mechanisms are needed at the local, regional, national or international scale is central here, especially to meet the needs of policymakers for decision-making (Carpenter 2010). In such systems, macroscopic patterns emerge, to large extent, from interactions at much lower scales of organization - individual agents, short time scales, and small spatial scales- and feed back to influence the dynamics at those microscopic scales, as assessed by Simon Levin (Levin 1992, 2010).

To understand and cope with the outcomes of such complex human environment systems, the contrasts across locations are particularly important (Daily et al. 2009). Thus a place-based approach is fundamental for a sound transition to sustainability. It is therefore essential, when trying to combine social justice with sustainability, to determine locally what is a good environment for the communities involved: One in which the improvement of environmental conditions stricto sensu (water quality, air, biodiversity, prudent use of resources, land and energy, etc.) will lead to improved living conditions; one in which technical devices and ecological processes-included in areas large enough to take into account imported sustainability-will lead to new lifestyles.

There is a gap, for example, between real environmental nuisance and its perception through the notion of quality of life (Moser and Weiss 2003). It should be noted, for example, that French espaces verts (green areas), do not necessarily bring people together. They also isolate people because their separate their homes. This aspect is in line with the Parisian history: the introduction of greenery by Haussmann was an attempt to control the use of public space by a technical approach based on hygienism (Luginbuhl 1992). Its main function was to bring more sunlight to the city and better the air circulation. The city life was marked by socio-spatial differentiation, virtually segregative, embodied in a type of revegetation reduced to espaces verts. Its role is finally to separate, to distinguish and to hide (Moret 2004). The very term espace vert (green area) reveals its real nature: “... by losing its name, the old urban garden or urban park is deprived of its positive attributes... the espace vert is no longer a place but rather an indistinct area whose boundaries are decided in the abstract world of the master-plans..." (Le Dantec and Le Dantec 1987). The current of Paris regional master plan proposes - as an important mean to foster sustainability - a quantitative objective of $10 \mathrm{~m}^{2}$ of public green area per inhabitant at the communal level. As though it were sufficient to display "green" to become suddenly sustainable.

\section{Two Gordian Knots: Intergenerational/Spatial Equity, Weak/Strong Sustainability}

In urban planning, one among the many challenges of sustainability is reestablishing the inclusiveness of the urban and social fabric-which is a complex taskinstead of popping-up buildings or housing estates without paying attention to the 
surroundings - which is so easy-The shape and outline of the cities, their vela, compose their urban form and determine their identities as well. To foster a good quality of life, there is need for contrasts, to meet and to adapt to the different individual aspiration among the inhabitants. Urban reconversion is crucial here: For example, industrial wastelands in the inner suburbs may be converted into offices or apartments, as part of eco-neighborhoods. Such sustainable actions are supposed to integrate urban habitus into the new projects.

But, more than often, things turn out very differently: "Exemplary" buildings and devices (Willbanks 2003) - all technical solutions — are often favored to the detriment of more holistic approaches, such as active land management and transformation of the urban fabric (differential densification, restructuring urban cores, etc.). To promote "green" buildings, elected officials accept to pay extra charges up to $20 \%$ of the original costs to obtain a Low-Energy label. They are less interested in the urban design, which is more important to create a real sustainable city but, of course, harder to implement and less profitable as an electoral issue. Besides, mayors, representatives and more generally elected officials adore showcasing constructions and they love them "brand new." They are so much more visible. Thus, too often, developers deliver turnkey new energy efficient construction and passive buildings in new neighborhoods improperly called "environmentally friendly" (Bierens de Haan and Dawson 2006). In many cases, vegetation, green technologies and exterior wood facing, camouflage very classical housing estates totally disconnected from their surroundings. Naturally, the regeneration of the existing urban and social fabric is not addressed here. There is no way to foster communities in such a context. The identity of place is usually extraordinarily weak for the people living there (Proshansky et al. 1983).

That kind of mechanism is the main reason why sustainability policies have finally few public backing, and are perceived unfair and technocratic. It explains the failure of numerous so-called sustainability actions to meet their target whether social or environmental: the people concerned do not take ownership of them. We should never forget that eventually, it is the current populations and societies that decide what is a "good environment," not the future generations who are not already here to push their ideas about what is a "good environment?" This bias speaks to us of the dilemma between preserving the environment for the generations to come-what we can call intergenerational equity - and prioritizing actual issues, such as quality of life or social justice - what we can call geographical equity-. There is a general equity principle, which we could also call fairness, at the heart of sustainable development (Cairns 2001). But in fact, there are many equities (Gibson et al. 2005). Usually, academic authors differentiate between intergenerational equity, geographical equity, procedural equity and, finally, interspecific equity (Haughton 1999). But in fact, the confrontation between intergenerational equity and geographical equity is what structure most strongly sustainability policies-as seen previously with the opposition between "weak" and "strong" sustainability—especially by urging on a better articulation between short-term (geographical equity, including social justice) and longterm (intergenerational equity). To make reference to Amartya Sen (Sen 2009), if there are obligations toward future generations, there are also obligations toward the 
actual generation. To combine sustainability issues and social justice, it is thus necessary first to make sustainability policies acceptable to the current populations, and naturally these populations are prone to favoring their interests - here and nowto issues placed in a distant future.

\section{Participatory Joint-Construction of Sustainability Policies}

Since, the effectiveness of sustainable policies lies largely in their acceptability-a highly subjective and rarely disinterested matter (Fischhoff et al. 1981) —and in their collective ownership, decision-making processes should be fundamentally a matter of collective decision. Beyond their procedural and prescriptive appearances, these decisions result from the confrontation — or the synergy — of choices made by a myriad of actors, each acting for its own concern and its own world vision. The more adequate framework to address such a situation is participatory jointconstruction of these policies (Andrews 2002): A boundary work, since it uses knowledge to inform negotiation among relevant actors in a politicized context; which corresponds to "political bargaining," according to the definition of William Clark (Clark et al. 2011), where actors with their own interests interact with heterogeneous knowledge producers. The point is co-producing collective decision through the interaction between society and science (Jasanoff and Wynne 1998), in an attempt to legitimize sustainability policymaking. This should include non-market organizations, local communities and individuals able to form self-determined user associations, in the continuity of Elinor Ostrom's work that showed that user communities with neighborhood governance could manage common resources more efficiently than the market or institutional structures (Ostrom 1998). There are three main obstacles:

- First, it is difficult to encompass all the actors (regional and local authorities, non-market institutions, NGOs, private companies, local store keepers, unions and chambers, landowners, etc.), even more to visualize the whole of their interactions.

- Second, how to take into account in the process the micro-decisions made by individuals and households, which have an indirect but strong influence on collective decisions. They are shaped by the moment and the economic status of the persons: Depending on whether-at moment t —-they feel (or are really) poor or not, they will not make the same choice if they are placed in the alternative of eating properly or going to the theater, thermally insulating their house or paying their bills. Ostentatious choices also play a big role, since they determine their position on the "social totem" (Frank 1999). Thus, to which point having a house of $1,500 \mathrm{~m}^{2}$ gives you more happiness than one of $1,000 \mathrm{~m}^{2}$ ? Not much more (Winkelmann 2012), but you need to "keep up with the Joneses" to conform with the social codes (Drakopoulos 2013), and because the demand is there, the size 
of the houses keeps rising inexorably on, accelerating the urban sprawl while denying more and more people the ability to house themselves properly.

- Third, all the actors have to consider the other members as legitimate partners, and the process of co-construction itself as satisfying the criteria of saliency, credibility, and legitimacy, which is all but evident to achieve (Mollinga 2008). Indeed, decision makers can be tempted to use the workshops to support decisions they have already made, or avoid responsibility by repackaging them as technical issues to be resolved by experts they control (Weingart 1983). Besides, how to convince each member of the panel that the content of the workshop is not biased in support of another member's agenda (Van Noordwijk et al. 2001).

To avoid these obstacles, it is necessary to pay great attention to two points:

- The process itself has to be flexible enough to be meaningful for actors coming from different "social worlds" (Jasanoff 1987; Turnhout 2009). As such, they necessarily exhibit a certain degree of vagueness and ambiguity, while maintaining consistency.

- There should be a focus on identifying the linkage between collective and individual decisions. By collective decisions, I mean decisions made by organizations or institutions (officials or not): urban form, transport policy and so on. By individual decisions, I mean the decisions taken by individuals or households autonomously, but that will aggregate to affect the collective decisions, while being influenced by them.

\section{Conclusions}

Combining the increase of everyone's wellbeing and social justice with sustainability is one of the greatest challenges today. To do so, sustainability policies, should focus more on the social process of decision-making. It means considering that the environment, far from being pure transcendence, is embedded in the societies. Quiet and nice unpolluted living environments have become emblèmes in the sense of Pierre Bourdieu and, as such, highly attractive - and expensive-areas. The human being builds a representation of the ecosystems he lives in and calls it "environment," out of the usages he makes of their resources: Takings (usage of air, water, minerals), inputs (pollution), alterations (housing, transport). Thus, the environment represents a more or less noisy neighborhood to which we have to adapt. A polluted environment can be a place where life is good. Conversely, an environment with clean air and clean water can be quite intolerable as evidenced by windswept segregated social-housing complexes settled in the middle of nowhere, where the quality of life is low (Mancebo 2010). It is impossible to determine whether a place is sustainable or not only by considering the factual date of environmental indicators. Instead, sustainability is an inclusive notion, which integrates social, cultural and economic aspects of the concerned societies. 
Promoting collective appropriation of sustainability policies implies that those who will be affected by them are involved in the process of decisionmaking, right from the beginning. When they are disconnected from the inhabitants and local communities needs, desires and definition of what a "good environment" is, these policies fail to meet their objectives. In such a context, it is crucial to design a new social contract that include stakeholders, neighborhood communities and groups of individuals among the major actors of sustainable development. This social contract is therefore and first of all a political process, which has to meet the following issues: What type of society do we want to live in? Which compromises between the goals and interests of the different groups? What linkage between one decision level and another?

The Millennium declaration proclaimed the "collective responsibility to uphold the principles of human dignity, equality and equity at the global level" (Stokke 2009). Prior to that, when the United Nations assigned the redaction of a report to the World Commission on Environment and Development in 1983, which is the source of sustainable development, its mission statement mentioned explicitly that its objectives were: "How to reduce inequality and poverty without damaging the environment granted to the future generations" (WCED 1987). It is time to go beyond the mantra, and try to do it concretely.

\section{References}

Andrews CJ (2002) Humble analysis: the practice of joint fact-finding. Praeger, Westport

Bierens de Haan C, Dawson J (2006) Entre écovillages et projets d'architectes: les écoquartiers. L'Urbanisme 348:41-44

Bigot R (2009) Regards sur les quartiers sensibles et les discriminations en France, Agence nationale pour la cohésion sociale et l'égalité des chances, Collections des rapports, $\mathrm{n}^{\circ} 271$, CREDOC, Paris

Billen G, Barles S, Chatzimpiros P, Garnier J (2012) Grain, meat and vegetables to feed Paris: where did and do they come from? Localizing Paris food supply areas from the eighteenth to the twenty-first century. Reg Environ Chang 12:325-335, Springer

Burton E (2001) The compact City and social justice. Housing, environment and sustainability, Housing Studies Association Spring Conference, University of York, York UK

Cairns J (2001) Equity, fairness, and the development of a sustainability ethos. Ethics Sci Environ Polit 1:1-7

Carpenter S (2010) Measuring and monitoring progress toward sustainability. In: Levin SA, Clark WC (eds) Toward a Science of Sustainability. CID Working Paper, $\mathrm{n}^{\circ}$ 196, pp 135-139, Harvard

Carpenter SR, Mooney HA, Agard J, Capistrano D, De Fries R, Diaz D, Dietz T, Duriappah A, Oteng-Yeboah A, Pereira HM, Perrings C, Reid WV (2009) Science for managing ecosystem services: beyond the millennium ecosystem assessment. Proc Natl Acad Sci 106:1305-1312

Christen M, Schmidt S (2012) A formal framework for conceptions of sustainability-a theoretical contribution to the discourse in sustainable development. Sustain Dev 20(6):400-410 
Clark WC, Tomich TP, Van Noordwijk M, Guston D, Catacutan D, Dickson N, McNie E (2011) Boundary work for sustainable development: natural resource management at the Consultative Group on International Agricultural Research (CGIAR). Proc Natl Acad Sci. doi:10.1073/ pnas.0900231108

Costanza R, Low BS, Ostrom E, Wilson J (2001) Institutions, ecosystems, and sustainability, Ecological economics series, Lewis Publishers, Albany GA

Daily GC, Polasky S, Goldstein J, Kareiva PM, Goldstein LP, Ricketts TH, Salzman J, Shallenberger R (2009) Ecosystem services in decision making: time to deliver. Front Ecol Environ 7:21-28

Daly H (1998) Reconciling internal and external policies for sustainable development. In: Dragun AK, Jacobson KM (eds) Sustainability and global economic policy. Elgar, Cheltenham

Dollar D, Kraay A (2000) Growth is good for the poor. World Bank, Washington, DC

Donzelot J (2004) La Ville à Trois Vitesses: Relégation, Périurbanisation, Gentrification. Revue Esprit 3-4:14-39

Drakopoulos SA (2013) Hierarchical needs, income comparisons, and happiness levels. Posit Psychol Perspec Qual Life Soc Indic Res Ser 51:17-32

Duréault J (2013) Architecture contemporaine et nature en ville, Engineering Thesis, Agrocampus Ouest, Angers

Elliot J (2006) An introduction to sustainable development. Routledge, London

Fischhoff B, Lichtenstein S, Slovic P, Derby S, Keeney R (1981) Acceptable risk. Cambridge University Press, Cambridge

François J-C, Ribardière A, Fleury A, Mathian H, Pavard A, Saint Julien T (2011) Les disparités de revenus des ménages franciliens - Analyse de l'évolution entre 1999 et 2007, Collection Présent pour avenir, DREAL d'Ile-de-France

Frank R (1999) Luxury fever: money and happiness in an era of excess. Princeton University Press paperback. The Free Press, Washington DC

Gibson R, Hassan S, Holtz S, Tansey J, Whitelaw G (2005) Sustainability assessment—criteria and processes. Earthscan, Oxford

Giddings B, Hopwood B, O’Brien G (2002) Environment, economy and society: fitting them together into sustainable development. Sustain Dev 10:187-196

Gueymard S, Faburel G (2008) Vécu environnemental et qualité de vie en Région Ile-de-France: une approche exploratoire des inégalités environnementales. PUCA, Paris

Haughton G (1999) Environmental justice and the sustainable city. J Plan Educ Res 18:233-243

Haughton G, Hunter C (1994) Sustainable cities. Kingsley, London

Hopwood B, Mellor M, O'Brien G (2005) Sustainable development: mapping different approaches. Sustain Dev 13:38-52

Jasanoff S (1987) Contested boundaries in policy-relevant science. Soc Stud Sci 17:195-230

Jasanoff S, Wynne B (1998) Science and decision-making. In: Rayner S, Malone EL (eds) Human choice and climate change: the societal framework. Battelle Press, Colombus OH, pp 1-87

Le Dantec D, Le Dantec J-P (1987) Le roman des jardins de France, éditions Terre de France, Plon

Leiserowitz A, Kates R, Parris T (2006) Sustainability values, attitudes, and behaviors: a review of multinational and global trends. Annu Rev Environ Resour 31:413-444

Lenton TM, Held H, Kriegler E, Hall JW, Lucht W, Rahmstorf S, Schellnhuber HJ (2008) Tipping elements in the earth's climate system. Proc Natl Acad Sci U S A 105(6):1786-1793

Levin SA (1992) The problem of pattern and scale in ecology. Ecology 73:1943-1967

Levin S (2010) Complex adaptive systems and the challenge of sustainability, In: SA Levin, WC Clark (eds) Toward a science of sustainability. CID Working Paper, $\mathrm{n}^{\circ}$ 196:129-134. Harvard

Luginbuhl Y (1992) Nature, paysage, environnement, obscurs objets du désir de totalité. In: Robic M-C (ed) Du milieu à l'environnement. Economica, Paris, pp 12-56

Mancebo F (2010) Le développement durable, 2nd edn. Collection U, Armand Colin, Paris

Mollinga PP (2008) Boundary work an the complexity of natural resource management. Crop Sci 50(Suppl 1):S1-S9

Moret J (2004) La biodiversité à Paris. In: Michaud Y (ed) L'université de tous les savoirs. Odile Jacob, pp 217-238 
Moser G, Weiss K (2003) Espaces de vie. Aspects de la relation homme-environnement. Armand Colin

Olander S, Johansson R, Niklasson B (2007) Aspects of stakeholder engagement in the property development process. In: Atkin B, Borgbrant J (eds) Proceedings of 4th Nordic Conference on Construction Economics and Organization, Research Report, $\mathrm{n}^{\circ} 18$. Lund University, Lund Sweden, pp 141-150

Ostrom E (1998) A behavioral approach to the rational choice theory of collective action. Am Polit Sci Rev 92(1):1-22

Pearce D, Markandya A, Barbier E B (1989) Blueprint for a green economy. Earthscan, Oxford

Proshansky HM, Fabian AK, Kaminoff R (1983) Place-identity: physical world socialization of the self. J Environ Psychol 3:57-83, Elsevier

Robinson J (2003) Squaring the circle? Some thoughts on the idea of sustainable development. Ecol Econ 48:369-384

Roseland M (1998) Towards sustainable communities: resources for citizens and their governments. New Society, Gabriola Island

Sen A (2009) The idea of justice. Allen Lane, London

Smith N (2002) New globalism, new urbanism: gentrification as global urban strategy. Antipode $34: 427-450$

Solow R (1974) The economics of resources or the resources of economics. Am Econ Rev 64:1-14

Stokke O (2009) The UN and development: from aid to cooperation. UN intellectual history project. Indiana University Press, Bloomington IN

Strayer DL, Beighley RE, Thompson LC, Brooks A, Nilsson C (2003) Effects of land cover on stream ecosystems: roles of empirical models and scaling issues. Ecosystems 6:407-423

Swart R, Robinson J, Cohen S (2003) Climate change and sustainable development: expanding the options. Clim Pol 3:19-40

Theys J, Emelianoff C (2001) Les contradictions de la ville durable. Le Débat 113:122-135

Turetsky MR, Harden JW, Friedli HR, Flannigan M, Payne N, Crock J, Radke L (2006) Wildfires threaten mercury stocks in northern soils. Geophys Res Lett 33:16

Turner MG (2010) A landscape perspective on sustainability Science. In: Levin SA, Clark WC (eds) Toward a science of sustainability. CID Working Paper, $n^{\circ} 196$. Harvard, pp 123-129

Turner BL, Robbins I, Robbins P (2008) Land-change science and political ecology: similarities, differences and implications for sustainability science. Ann Rev Environ Resour 33:295-316

Turhnout E (2009) The effectiveness of boundary objects: the case of ecological indicators. Sci Public Policy 36(5):403-412

UN-HABITAT (2008) State of the World Cities Report 2008-2009 - Harmonious Cities

Van Noordwijk M, Tomich, Verbist (2001) Negotiation support models for integrated natural resource in tropical forest margins. Ecol Soc 5(2), article 21

Von Weizsäcker EU, Lovins AB, Lovins LH (1997) Factor four: doubling wealth, halving resource use. Earthscan, Oxford

WCED (1987) Our common future. Oxford University Press, Oxford

Weingart P (1983) Verwissenschaftlichung der Gesellschaft-Politisierung der Wissenschaft. Zeitschrift für Soziologie 12:225-241

Werling BP, Gratton C (2008) Influence of field margins and landscape context on ground beetle diversity in Wisconsin (USA) potato fields. Agric Ecosyst Environ 128:104-108

Wilbanks TJ (2003) Integrating climate change and sustainable development in a place-based context. Clim Pol 3:147-154

Winkelmann R (2012) Conspicuous consumption and happiness. J Econ Psychol 33(1):183-191 